\title{
Effects of Training with Different Modes of Strength Intervention on Psychosocial Disorders in Adolescents: A Systematic Review and Meta-Analysis
}

\author{
Guillermo Barahona-Fuentes ${ }^{1,2, *(\mathbb{C})}$, Álvaro Huerta Ojeda ${ }^{2}\left[\right.$ and Luis Chirosa-Ríos ${ }^{1}[(]$ \\ 1 Department Physical Education and Sports, Faculty of Sport Sciences, University of Granada, \\ 18011 Granada, Spain; lchirosa@ugr.es \\ 2 Grupo de Investigación en Salud, Actividad Física y Deporte ISAFYD, Universidad de Las Américas, \\ Sede Viña del Mar 2531098, Chile; achuertao@yahoo.es \\ * Correspondence: danielbarahonaf@gmail.com; Tel.: +56-9-63989823
}

check for

updates

Citation: Barahona-Fuentes, G.; Huerta Ojeda, Á.; Chirosa-Ríos, L. Effects of Training with Different Modes of Strength Intervention on Psychosocial Disorders in Adolescents: A Systematic Review and Meta-Analysis. Int. J. Environ. Res. Public Health 2021, 18, 9477. https://doi.org/10.3390/ ijerph18189477

Academic Editor: Dylan P. Cliff

Received: 30 July 2021

Accepted: 1 September 2021

Published: 8 September 2021

Publisher's Note: MDPI stays neutral with regard to jurisdictional claims in published maps and institutional affiliations.

Copyright: (c) 2021 by the authors. Licensee MDPI, Basel, Switzerland. This article is an open access article distributed under the terms and conditions of the Creative Commons Attribution (CC BY) license (https:/ / creativecommons.org/licenses/by/ $4.0 /)$.

\begin{abstract}
Physical exercise has a positive impact on anxiety and depression. However, the evidence that associates strength training with a decrease in adolescents' psychosocial disorders is scarce. Consequently, the objective was to analyze the effects of training with different modes of strength intervention on anxiety, stress, and depression in adolescents. The search was designed according to PRISMA ${ }^{\circledR}$. We searched WoS, Scopus, SPORTDiscus, PubMed, and MEDLINE (2010-2020). Methodological quality and risk of bias were assessed with the Cochrane Collaboration. The analysis was carried out with a standardized mean difference (SMD) pooled using the Hedges $g$ test (95\% CI). The Main Outcome Measures were: anxiety, stress, and depression in adolescents post strength training. Nine studies were included in the systematic review and seven in the meta-analysis. These studies showed a large and significant effect of strength training on anxiety (SMD $=-1.75 ; \mathrm{CI}=95 \%$ : $-3.03,-0.48 ; p=0.007)$ and depression (SMD $=-1.61 ; \mathrm{CI}=95 \%:-2.54,-0.67, p=0.0007)$. In conclusion, training with different modes of strength intervention have shown control over anxiety and depression in adolescents. However, conventional strength training seems to have better results than other modes of strength intervention.
\end{abstract}

Keywords: strength training; anxiety; stress; depression; adolescence

\section{Introduction}

Currently, a large part of the population has been affected in terms of quality of life due to negative alterations in mental health [1]. In this sense, variables such as anxiety are considered an emotional reaction consisting of a unique combination of feelings of tension, apprehension, and nervousness, as well as unpleasant thoughts of worry and physiological changes associated with the activation of the autonomic nervous system [2]. Stress is defined as a psychological condition that occurs when a subject observes a substantial imbalance between the demands that he or she endures and his or her ability to meet them [3]. Moreover, depression is defined as a mood condition, such as excessive sadness and/or a significantly reduced experience of pleasure. These mental health disorders are called psychosocial disorders [4,5]. These psychosocial disorders have been identified in athletes [6], workers [1], university students [5,7], and adolescents [8]. Specifically, an adolescent psychosocial disorder can lead to decreased academic performance, increased drug use and consumption, and increased potential for suicidal ideation [8] and has even been associated with decreased interest in physical activity [9]. The latter has been considered one of the determining factors for reducing anxiety, stress, and depression levels [10].

In this context, physical activity and exercise practice improve physical fitness, resulting in beneficial effects on physical and cognitive health in children and adolescents [11]. 
An example of this is the anxiolytic effect of aerobic exercise [12] in patients with anxiety and stress disorders [13,14], despite this evidence, which shows a positive effect of aerobic physical exercise on anxiety and stress in children and adolescents, leaving a vast space of ignorance about the effect of strength training on psychosocial parameters [15]. Another mechanism by which physical activity and exercise are related to better mental health is brain development in the population that practices physical activity and exercise [16]. In this regard, it has been shown that high levels of maximum oxygen consumption are related to a greater volume of the left medial prefrontal cortex and an increase in the surface areas of the parietal cortex in adolescents [17]. In parallel, it has been found that subjects with a better physical shape have higher hippocampus volumes [18]. Conversely, a lower hippocampus volume has also been associated with the development and increased depression levels in adolescents [19-22].

As mentioned above, the practice of physical activity and exercise may be involved in brain development [16] and, consequently, in psychosocial disorders [23]. Although the benefits of aerobic training on anxiety, stress, and depression are well established in the literature [14,15], evidence from strength training on psychosocial disorders is scarce [24]. Specifically, strength training is an exercise that involves the voluntary activation of specific muscle groups of the skeletal muscle against an external resistance [25]. There is training with different modes of strength intervention that allow the development of muscular strength: conventional strength training (which consists of systematic executions of concentric and eccentric muscle contractions voluntarily against external loads) [26]; concurrent training (which includes a combination of aerobic and strength training) [27]; strength training on a vibrating platform (which includes the use of vibrations to induce muscle contraction) [28]; strength training through CrossFit ${ }^{\circledR}$ (which consists of a combination of strength exercises performed through a circuit) [29], and plyometric training (which are jumping exercises) [30]. This training type allows the development and increase of skeletal muscle mass, strength, power, and muscle endurance [31-33]. Concerning optimal muscle development resulting from strength training, it has been shown that subjects with greater muscle mass have a better quality of life [34]. Conversely, low levels of muscle strength are a reflection of poor muscle quality [35]. In this sense, muscle quality describes the functional physiological capacity of muscle tissue [36]. This tissue must carry out various functions, such as contractions, metabolism, and electrical conduction [36]. At the same time, it has been observed that high muscle quality plays a role in preventing chronic diseases [37]. It has also been shown that men and women with a high subcutaneous adipose tissue content [38], high-fat mass, and low lean mass [39] have decreased muscle quality $[38,39]$.

Based on these antecedents, it is possible that an excellent physical condition-reflected in good muscular quality as a result of strength training [35] — might be capable of making substantial changes in brain development [16]. This may decrease anxiety and stress levels, as well as depression in adolescents. Unfortunately, these associations are not sufficiently studied; so far, it seems that only speculations were made. On the other hand, there would be indications that strength training would improve anxiety levels [24]. In this regard, a meta-analysis by Gordon et al. [24] showed that strength training significantly improved anxiety symptoms in healthy adult participants and adult participants with a physical or mental illness. However, these researchers [24] did not evaluate the anxiety, stress, and/or depression of the adolescent participants; thus, there is insufficient knowledge about the effects of training methods on adolescents' anxiety, stress, and depression levels.

Consequently, the objective of this systematic review and meta-analysis was to analyze the effects of training with different modes of strength intervention on psychosocial disorders of anxiety, stress, and depression in adolescents. 


\section{Materials and Methods}

This systematic review and meta-analysis followed the preferred reporting items for systematic reviews and meta-analyses (PRISMA) guidelines [40] and the Cochrane Collaboration guidelines to evaluate the risk of studies bias. The protocol of this review was registered in PROSPERO (CRD42021271440)

\subsection{Eligibility Criteria}

Articles were eligible if they were published or in-press in a peer-reviewed journal, with full text in English, Spanish, French, Portuguese, and German. Search limits were articles published in the last ten years (January 2010 to June 2020). Such restriction has the objective to show a current panorama of the analyzed studies [41,42]. The literature search was conducted following the guidelines for systematic reviews and meta-analysis (PRISMA) [40]. For this purpose, population, intervention, comparators, and outcomes (PICO) were established as follows: (i) participants were adolescents explicitly or implicitly diagnosed with any form of anxiety, depression, and stress (for example, Beck's Depression Inventory (BDI) [43], Children's Depression Inventory (CDI) [44], Profile of Mood States (POMS) [45], Premenstrual Symptoms Impact Survey (PMSIS) [46], State-trait Anxiety Inventory (STAI) [47], Children's Manifest Anxiety Scale (CMAS) [48], Kessler Psychological Distress Scale (K10) [49], among others [50]); (ii) Only those interventions that, within their protocol, have used different modes of strength training intervention, regardless of their modality (alone or combined), were considered; (iii) The comparators were control groups that had not performed any training protocols; (iv) The results were any effects (positive or negative) on indicators of anxiety, stress, and depression; (v) The study design was limited to experimental studies. Studies that did not meet the eligibility criteria were excluded. The discrepancies found were resolved by the consensus of the researchers.

\subsection{Information Sources and Search}

The search identified articles published in the following databases: Web of Science (WoS), Scopus, SPORTDiscus, PubMed, and Medline. In each of the databases, the title, abstract, and keyword search fields were searched. The following keywords, combined with Boolean operators (AND/OR), were used (["strength training" OR "resistance training" OR "weight training" OR "concurrent training" OR "combined training" OR "cross training" OR "crossFit" OR "plyometric training"] AND ["adolescent" OR "adolescence" OR “teenager" OR "teen"] AND ["anxiety" OR "stress" OR “depression" OR “depressive disorder"]). Two authors searched and reviewed the studies, both deciding whether the inclusion of the studies was appropriate. In case of disagreement, a third author was consulted.

\subsection{Data Extraction}

The data collection was: author, year, journal, target, sample, number of participants, age, dependent and independent variable, treatment, outcomes, performance, experimental, and control groups. One author extracted the continuous data for the meta-analysis and a second author verified them. In case of disagreement, the third author was consulted. The values were entered in a spreadsheet in the Excel software, and then the Review Manager software was used (version 5.4) (Copenhagen, Denmark: The Nordic Cochrane Centre, The Cochrane Collaboration, 2014).

\subsection{Risk of Publication Bias between Studies}

The risk of publication bias between studies was only carried out in those part of the meta-analysis. Publication bias was assessed using Egger's statistical test. This test determined the presence of bias at $p \leq 0.05$ [51]. Funnel plots were created to interpret the general effect, followed by an Egger's statistic to confirm or refute publication bias. 


\subsection{Methodological Quality and Risk of Bias of Individual Studies}

The methodological quality and risk of bias of each study selected for the meta-analysis were evaluated using the Cochrane Collaboration guide [52]. The list was divided into six different domains: selection bias (random sequence generation, allocation concealment), performance bias (blinding of participants and personnel), detection bias (blinding of outcome assessment), attrition bias (incomplete outcome data), reporting bias (selective reporting), and other types of bias (declaration of conflict of interest). For each item, the answer to a question was considered; when the question was answered with a "Yes," the bias was low; when it was "No," the bias was high; when it was "Unclear," the possible bias was connected to a lack of information or uncertainty.

\subsection{Summary Measures and Synthesis of Results in Studies}

For the analysis and interpretation of results in this systematic review and metaanalysis, the effect of strength training on anxiety, stress, and depression levels in adolescents was examined as a primary outcome. The meta-analysis was only carried out if the selected study complied with an intervention with a strength training protocol, contained a control group and an experimental group, and those in which the variables of anxiety, stress, and/or depression had presented pre- and post-intervention evaluations. Thus, if any study did not meet these characteristics, it could not be part of the meta-analysis and would only be considered part of the systematic review. In order to evaluate the quality of the experiments and interpret the risk of bias values, Review Manager version 5.4 was used (Copenhagen, Denmark: The Nordic Cochrane Centre, The Cochrane Collaboration, 2014). The same software was used to perform a descriptive and statistical analysis of the meta-analysis. To compare the effects of the experimental group (EG) that performed resistance training versus a control group (CG) that contained no intervention, the number of participants, standardized mean difference (SMD), and standard error of SMD were analyzed for each study. Hedges' g test was used to calculate the SMD of each study [53]. The overall effect and the $95 \%$ confidence interval (CI) were calculated by weighting the SMD by inverse variance. Additionally, the SMD of both the EG and CG groups were subtracted to obtain the effect size (ES), which was used together with the pooled SD of change to calculate the variance (ES = [mean EG - mean CG]/SD). To interpret the magnitude of the ES, Cohen's criteria were: $<0.2$, trivial; $0.2-0.5$, small; $0.5-0.8$, moderate; and $>0.8$, large [54].

Due to real heterogeneity rather than chance, the I2 statistic was calculated as an indicator of the studies' total observed variation. I2 values are included from 0 to $100 \%$, representing: a small amount of inconsistency (between $25 \%$ and $50 \%$ ); a medium amount of heterogeneity (between $50 \%$ and $75 \%$ ); and a large heterogeneity (when the I2 value was higher than $75 \%$ ). In this sense, low, moderate, and high adjectives would be accepted, referring to I2 values of $25 \%, 50 \%$, and $75 \%$, respectively, although a restrictive categorization would not be adequate in all circumstances [55].

\section{Results}

\subsection{Studies Selection}

The literature search through electronic databases identified 375 articles, of which 189 were duplicates. The remaining 166 articles were filtered by title and abstract, and 20 studies remained to be read and analyzed. After reviewing those 20 studies, 11 were eliminated because they did not meet the inclusion criteria. As a result, nine articles were included in the systematic review. Of these nine, two did not meet the meta-analysis characteristics, thus only seven studies were part of the meta-analysis. The search strategy and study selection are shown in Figure 1. 


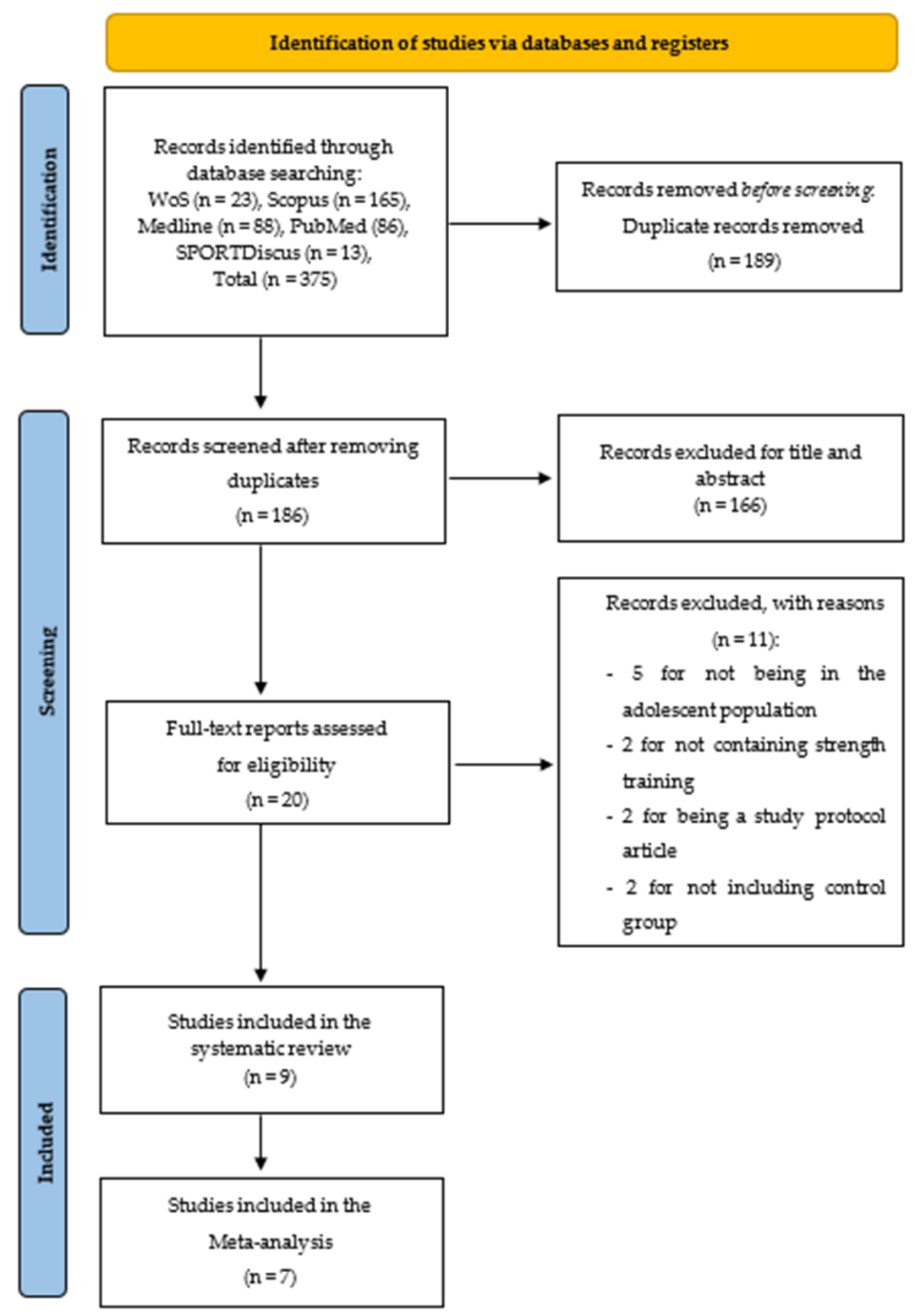

Figure 1. PRISMA flow diagram of articles that were selected.

Of the nine studies included in the systematic review and meta-analysis, one determined the effects of strength training on anxiety levels [56], four on depression [57-60], and three used anxiety and depression variables together [61-63]. Besides, one article evaluated mental health (emotional, psychological, and social well-being) [64], which is commonly associated with psychosocial anxiety disorders and depression [65]. On the other hand, strength training was reflected through the following intervention modes: CrossFit Teens ${ }^{\mathrm{TM}}$ [64], concurrent training (CT) combining aerobic and strength exercises [56-58,61,63], vibration platform strength training [60,62], and conventional strength training $[58,59,62]$. The characteristics and type of strength training protocol of the studies selected in this systematic review and meta-analysis are presented in Tables 1 and 2. 
Table 1. Characteristics of the studies included in the systematic review and meta-analysis.

\begin{tabular}{|c|c|c|c|c|c|}
\hline Author & Objective & Sample & Variables & Results & Physical Performance \\
\hline \multicolumn{6}{|c|}{ Effects of Strength and Concurrent Training on Anxiety and Depression } \\
\hline Costigan et al. [61] & $\begin{array}{l}\text { To evaluate the efficacy of two } \\
\text { high-intensity interval training } \\
\text { (HIIT) protocols for improving } \\
\text { cognitive and mental health } \\
\text { outcomes (executive function, } \\
\text { psychological well-being, } \\
\text { psychological distress, and } \\
\text { physical self-concept) in } \\
\text { adolescents }\end{array}$ & $\begin{array}{c}65 \text { adolescents, } 45 \mathrm{M} \text { and } 20 \\
\text { W CG: } 22 \text { (15.6 } \pm 0.6) \text { EG1: } 21 \\
(15.7 \pm 0.7) \text { EG2: } 22 \\
(15.5 \pm 0.6)\end{array}$ & $\begin{array}{l}\text { IV: HIIT (EG1); HIIT + ST (EG2) } \\
\text { DV: Cognitive and mental health } \\
\text { (evaluated through the Kessler } \\
\text { Psychological Distress Scale). }\end{array}$ & ns & - \\
\hline Eather et al. [64] & $\begin{array}{l}\text { To investigate the effectiveness of } \\
\text { the CrossFit Teens resistance } \\
\text { training program for improving } \\
\text { mental health outcomes in } \\
\text { adolescents and to explore } \\
\text { potential moderators and } \\
\text { mediators. }\end{array}$ & $\begin{array}{l}96 \text { adolescents }(15.5 \pm 0.50) \\
\text { CG: } 45 \\
\text { EG: } 51\end{array}$ & $\begin{array}{l}\text { IV: CrossFit Teens. } \\
\text { DV: Mental health (evaluated } \\
\text { through the Strength and } \\
\text { Difficulties Questionnaire) }\end{array}$ & ns & - \\
\hline ElDeeb et al. [62] & $\begin{array}{l}\text { To compare the effect of } \\
\text { whole-body vibration and } \\
\text { resistive exercise on } \\
\text { premenstrual symptoms in } \\
\text { adolescents with premenstrual } \\
\text { syndrome. }\end{array}$ & $\begin{array}{c}60 \text { young sedentary W } \\
\text { CG: } 20(17.9 \pm 1.16) \text { EG1: } 20 \\
(17.7 \pm 1.17) \text { EG2: } 20 \\
(17.3 \pm 1.41)\end{array}$ & $\begin{array}{l}\text { IV: VPT (EG1); ST (EG2). } \\
\text { DV: Premenstrual symptoms, } \\
\text { anxiety, and depression } \\
\text { (evaluated through the } \\
\text { Premenstrual Symptoms Impact } \\
\text { Survey) }\end{array}$ & $\begin{array}{c}\text { EG1 and EG2, } \downarrow(p<0.05) \\
\text { their levels of anxiety and } \\
\text { depression, significantly. }\end{array}$ & - \\
\hline
\end{tabular}


Table 1. Cont.

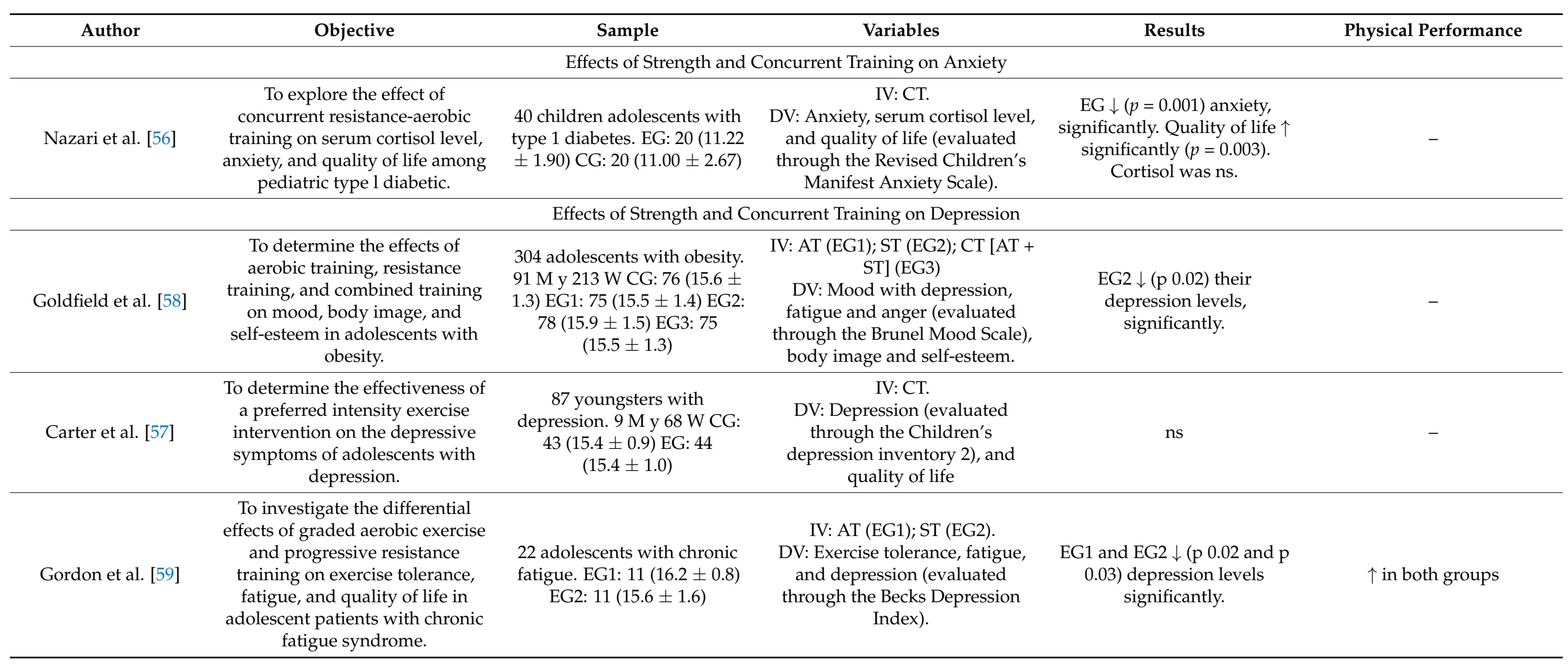


Table 1. Cont.

\begin{tabular}{|c|c|c|c|c|c|c|c|c|}
\hline Author & \multicolumn{3}{|c|}{ Objective } & Sample & Variables & \multicolumn{2}{|c|}{ Results } & Physical Performance \\
\hline Wunram et al. [60] & $\begin{array}{r}\text { To i } \\
\text { effe } \\
\mathrm{w} \\
\\
\mathrm{a} \\
\mathrm{r} \\
\mathrm{a} \\
\mathrm{maj} \\
\text { er }\end{array}$ & $\begin{array}{l}\text { e the fe } \\
\text { of a hi } \\
\text { vibra } \\
\text { gi as a } \\
\text { sive tr } \\
\text { n-naive } \\
\text { s with } \\
\text { ion co } \\
\text { cycling }\end{array}$ & $\begin{array}{l}\text { lity and } \\
\text { equency } \\
\text { WBV) } \\
\text { ent in } \\
\text { tient } \\
\text { losed } \\
\text { ed to an } \\
\text { lition. }\end{array}$ & $\begin{array}{c}64 \text { teenagers with depression. } \\
\text { EG1: } 20 \text { (16.1 } \pm 1.2) \text { EG2: } 21 \\
(15.9 \pm 1.2) \text { CG: } 23 \\
(15.7 \pm 1.1)\end{array}$ & $\begin{array}{l}\text { IV: Ergometer (EG1); VPT (EG2). } \\
\text { DV: Depressive symptoms } \\
\text { (evaluated through the } \\
\text { Depressionsinventar für Kinder } \\
\quad \text { und Jugendliche). }\end{array}$ & \multicolumn{2}{|c|}{$\begin{array}{l}\text { Depression was ns after } 6 \mathrm{w} \text {. } \\
\text { Depression } \downarrow \text { after } 26 \mathrm{w} \text { EG1 } \\
(p=0.037) \text { y EG2 }(p=0.042) \text {, } \\
\text { significantly. }\end{array}$} & $\begin{array}{l}\mathrm{EG} 1: \uparrow \\
\mathrm{EG} 2:=\end{array}$ \\
\hline \multicolumn{9}{|c|}{$\begin{array}{l}\downarrow: \text { decreases; =: equal; } \uparrow: \text { increase; -: not measured; +: plus; AT: aerobic training; CG: control group; CT: concurrent training; DV: dependent variable; EG: experimental group; HR: heart rate; IV: independent } \\
\text { variable; M: men; min: minutes; MR: maximum repetitions; ns: non-significant; P: pause; R: repetitions; S: sessions; s: seconds; ST: strength training; VO }{ }_{2} \text { max: maximum oxygen consumption; VPT: vibration } \\
\text { platform training; W: women; w: weeks; Wo: work; x: for. }\end{array}$} \\
\hline Author & $\mathbf{W}$ & $\mathrm{S} / \mathrm{w}$ & & Methodology & Reps (n) & Sets (n) & Intensity/Load & Rest Between Sets \\
\hline \multirow[b]{2}{*}{$\begin{array}{l}\text { Costigan et al. } \\
{[61]}\end{array}$} & 8 & 3 & $\begin{array}{r}\text { Gross } \\
\text { (shuttle }\end{array}$ & $\begin{array}{c}\text { AT } \\
\text { HIIT (EG1); } \\
\text { motor cardiorespiratory exercises } \\
\text { runs, jumping jacks, and skipping) }\end{array}$ & $\begin{array}{l}\text { Maximum number of } \\
\text { repetitions in } 30 \mathrm{~s} \text { for } \\
8-10 \mathrm{~min}\end{array}$ & NR & $\begin{array}{l}92.4 \% \\
(\mathrm{HR} \max )\end{array}$ & $30 \mathrm{~s}$ \\
\hline & 8 & 3 & $\begin{array}{r}\text { (shutt } \\
\text { com }\end{array}$ & $\begin{array}{c}\text { CT } \\
\text { [HIIT + ST] (EG2); } \\
\text { tle runs, jumping jacks, skipping, } \\
\text { bined with body weight squats, } \\
\text { push-ups) }\end{array}$ & $\begin{array}{l}\text { Maximum number of } \\
\text { repetitions in } 30 \mathrm{~s} \text { for } \\
8-10 \mathrm{~min}\end{array}$ & NR & $\begin{array}{l}91.8 \% \\
(\mathrm{HR} \max )\end{array}$ & $30 \mathrm{~s}$ \\
\hline Eather et al. [64] & 8 & 2 & $\begin{array}{l}\text { (squat } \\
\text { push-1 }\end{array}$ & $\begin{array}{l}\text { CrossFit } \\
\text { jumps, lunges, medicine ball toss, } \\
\text { ups, deadlifts and shoulder press) }\end{array}$ & $\begin{array}{l}\text { Depending on the } \\
\text { performance } \\
\text { obtained } W \text { previous }\end{array}$ & NR & NR & NR \\
\hline
\end{tabular}


Table 2. Cont.

\begin{tabular}{|c|c|c|c|c|c|c|c|}
\hline Author & W & $S / w$ & Methodology & Reps (n) & Sets (n) & Intensity/Load & Rest Between Sets \\
\hline Suh et al. [63] & 12 & 1 & $\begin{array}{c}\text { CT } \\
{[\mathrm{AT}+\mathrm{ST}]} \\
(10 \mathrm{~min} \text { of leg extension and leg press, and } \\
40 \text { min of cycling and walking on the } \\
\text { treadmill) }\end{array}$ & $\begin{array}{l}\mathrm{ST}=12 \\
\mathrm{AT}=1\end{array}$ & $\begin{array}{l}\mathrm{ST}=5 \\
\mathrm{AT}=1\end{array}$ & $\begin{array}{c}\mathrm{ST}=70 \% \\
(1-\mathrm{MR}) \\
\mathrm{AT}=70-80 \%(\mathrm{HR} \\
\max )\end{array}$ & NR \\
\hline \multirow{2}{*}{ ElDeeb et al. [62] } & 12 & 3 & $\begin{array}{l}\text { VPT } \\
\text { (with a knee angle of } 150^{\circ} \text { and vibration } \\
\text { amplitude of } 1 \mathrm{~mm} \text { ). }\end{array}$ & 1-min & $3-10$ & $20 \mathrm{~Hz}$ & 1-min \\
\hline & 12 & 3 & $\begin{array}{c}\text { ST } \\
\text { (exercises for shoulder, elbow, hip, and } \\
\text { knee joints). }\end{array}$ & $3-12$ & 1 for shoulder & $\begin{array}{l}60-70 \% \\
(1-\mathrm{MR})\end{array}$ & 2-min \\
\hline Nazari et al. [56] & 16 & 3 & $\begin{array}{c}\text { CT } \\
{[\text { ST }+ \text { AT] }} \\
\text { (20-min Pilates exercises }+20-\text { min } \\
\text { bodyweight exercises. Then, 20-min AT } \\
\text { including 10-min of V-forward, V-back and } \\
\text { 10-min of march) }\end{array}$ & $\mathrm{ST}=8-12$ & $\mathrm{ST}=2-3$ & $\begin{array}{c}\mathrm{ST}=\mathrm{NR} \\
\mathrm{AT}=50-75 \%(\mathrm{HR} \\
\max )\end{array}$ & $\begin{array}{c}\mathrm{ST}=30 \mathrm{~s} \\
\mathrm{AT}=2-\mathrm{min}\end{array}$ \\
\hline \multirow{3}{*}{$\begin{array}{l}\text { Goldfield et al. } \\
\text { [58] }\end{array}$} & 22 & 3 & $\begin{array}{c}\text { AT (EG1); } \\
\text { (45-min of Treadmill, elliptical, and/or } \\
\text { bicycle) }\end{array}$ & 1 & 1 & $\begin{array}{c}65-85 \% \\
\text { (HR max) }\end{array}$ & NR \\
\hline & 22 & 3 & $\begin{array}{c}\text { ST (EG2); } \\
\text { (Seven exercises with weight machines or } \\
\text { free weights) }\end{array}$ & $8-15$ & $2-3$ & $\begin{array}{c}80 \% \\
(1-\mathrm{MR})\end{array}$ & NR \\
\hline & 22 & 3 & $\begin{array}{c}\mathrm{CT} \\
{[\mathrm{AT}+\mathrm{ST}](\mathrm{EG} 3)}\end{array}$ & $\begin{array}{c}\mathrm{AT}=1 \\
\mathrm{ST}=8-15\end{array}$ & $\begin{array}{c}\mathrm{AT}=1 \\
\mathrm{ST}=2-3\end{array}$ & $\begin{array}{c}\mathrm{AT}=65-85 \%(\mathrm{HR} \\
\max ) \\
\mathrm{ST}=80 \% \\
(1-\mathrm{MR})\end{array}$ & NR \\
\hline
\end{tabular}


Table 2. Cont.

\begin{tabular}{|c|c|c|c|c|c|c|c|}
\hline Author & W & $\mathrm{S} / \mathrm{w}$ & Methodology & Reps (n) & Sets (n) & Intensity/Load & Rest Between Sets \\
\hline Carter et al. [57] & 6 & 2 & $\begin{array}{c}\text { CT } \\
{[\mathrm{AT}+\mathrm{ST}]} \\
\text { (abdomen and back exercises; two medicine } \\
\text { ball arm exercises from the supine position; } \\
\text { rebound, static and dynamic balance } \\
\text { exercises on a trampoline; bodyweight } \\
\text { squatting exercise against a wall and } \\
\text { stationary bicycle) }\end{array}$ & NR & NR & NR & NR \\
\hline \multirow{2}{*}{ Gordon et al. [59] } & 4 & 5 & $\begin{array}{c}\text { AT } \\
\begin{array}{c}(20-40 \text { min of stationary bicycle, and } \\
\text { treadmill) }\end{array}\end{array}$ & NR & NR & $\begin{array}{c}40-60 \% \\
\text { (of reserve HR) }\end{array}$ & NR \\
\hline & 4 & 5 & $\begin{array}{c}\text { ST } \\
\text { (16 exercises combine upper and lower } \\
\text { body and core stability }\end{array}$ & $10-15$ & 1 & NR & NR \\
\hline $\begin{array}{c}\text { Wunram et al. } \\
\text { [60] }\end{array}$ & 6 & 4 & $\begin{array}{c}\text { AT } \\
\text { (Ergometer) }\end{array}$ & NR & NR & & \\
\hline
\end{tabular}

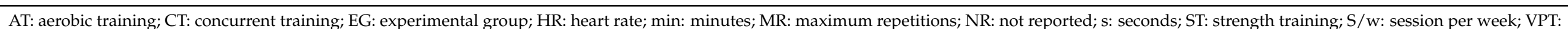
vibration platform training; w: weeks. 


\subsubsection{Risk of Bias among Studies}

Egger's analysis suggested that the primary variables evaluated in the studies that were part of the meta-analysis showed publication bias after strength training and concurrent training: (a) anxiety: $\mathrm{z}=2.69, p=0.007$; (b) depression: $\mathrm{z}=3.38, p=0.0007$ (Figure 2).

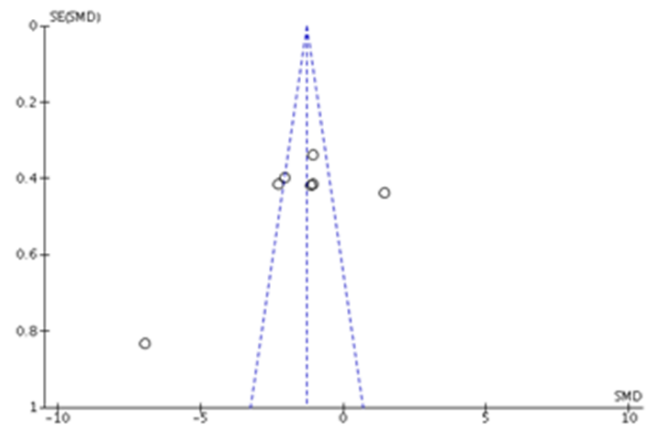

(a)

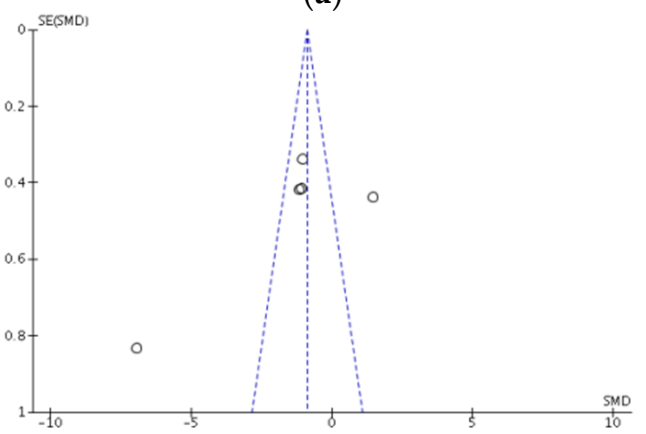

(c)

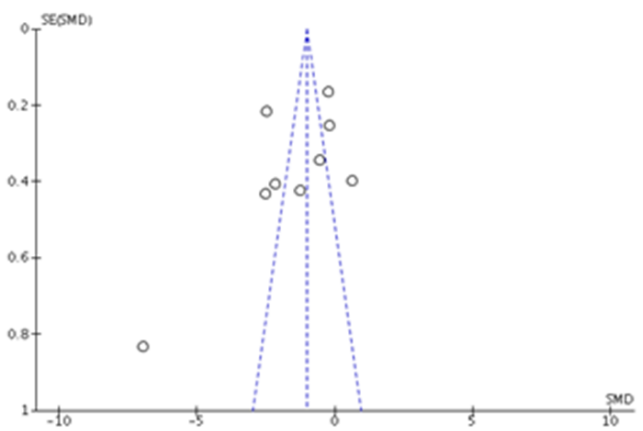

(b)

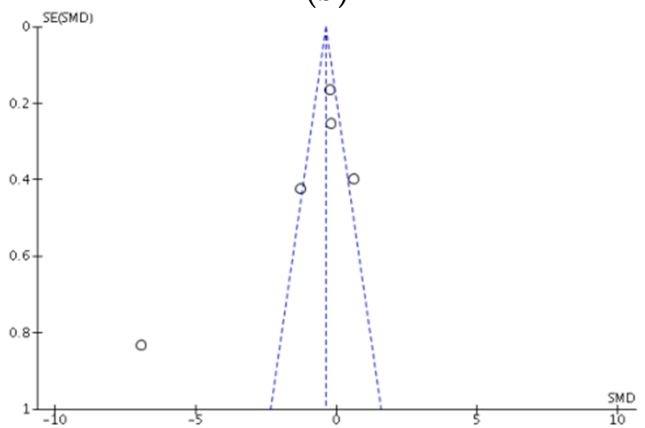

(d)

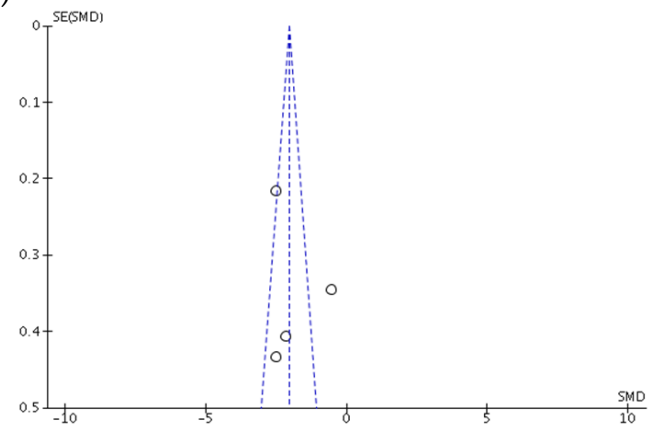

(e)

Figure 2. The standard error in different modes of strength intervention for anxiety and depression. (a) strength training and concurrent training for anxiety; (b) strength training and concurrent training for depression; (c) concurrent training for anxiety; (d) concurrent training for depression; (e) strength training for depression; SE: standard error; SMD: standardized mean difference.

\subsubsection{Assessment of Methodological Quality and Risk of Bias of Individual Studies}

The assessment of the methodological quality and risk of bias of the seven studies selected for meta-analysis showed that the study developed by Suh et al. [63] had: a high risk of bias for the domain of selection bias (random sequence generation, allocation concealment); unclear risk for performance bias (blinding of participants and research staff); detection bias (blinding of outcome assessment); and dropout bias (incomplete outcome data). Likewise, Goldfield et al. [58] showed an unclear risk of bias for dropout bias. On the other hand, the rest of the studies $[56,57,60-62]$ showed a low risk of bias for all domains. Full details of each study and domain are presented in Figures 3 and 4. 


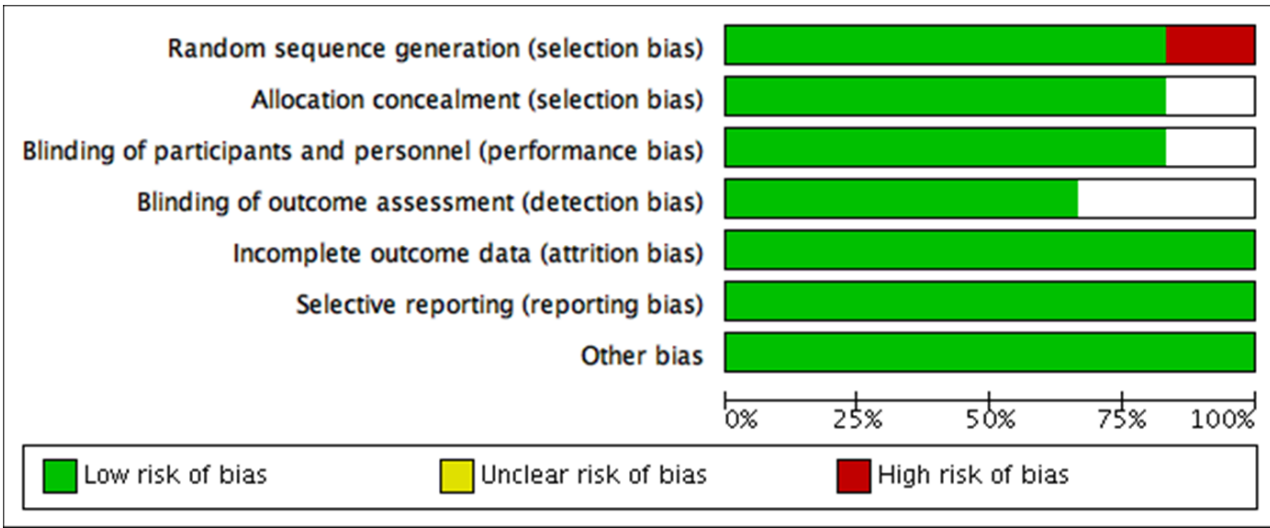

Figure 3. Risk of bias graph: review authors' judgements about each risk of bias item presented as percentages across all included studies.

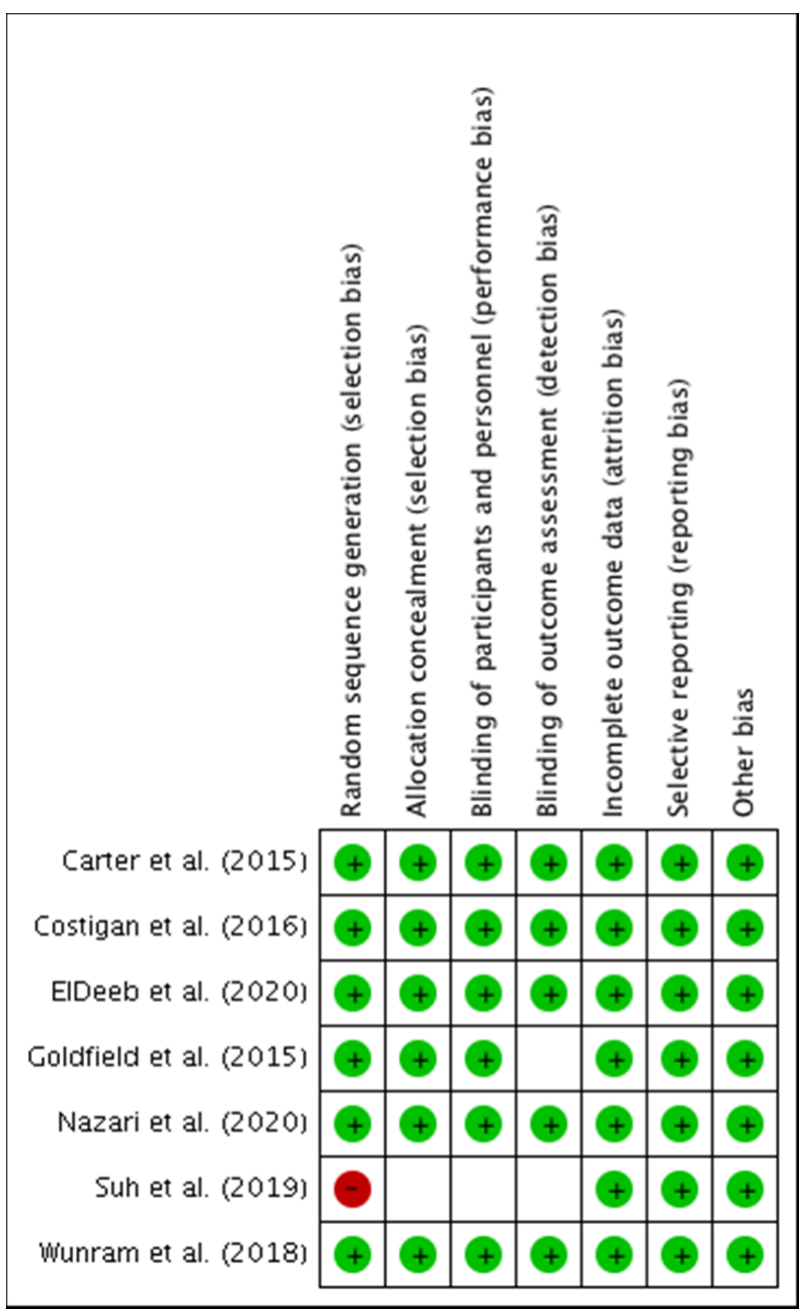

Figure 4. Risk of bias summary: Review authors' judgements about each risk of bias item for each included study.

\subsection{Meta-Analysis}

\subsubsection{Effects of Different Strength Training Methods on Anxiety Levels}

Four studies were considered for this analysis [56,61-63]. However, Suh et al. [63] included three anxiety questionnaires in the research with different results. On the other hand, ElDeeb et al. [62] included two different pieces of training for strength intervention 
in the research design, one on a vibrating platform and the other conventional. For the meta-analysis, the study by Suh et al. [63] was considered as three independent designs. Similarly, the study by ElDeeb et al. [62] was considered as two independent training protocols. Therefore, seven studies were included in the meta-analysis that calculated the effect of training with different modes of strength intervention on anxiety levels. Figure 5 shows that training with different modes of strength intervention have a large and significant effect on the anxiety level (SMD = -1.75; CI =95\%: $-3.03,-0.48 ; p=0.007$ ). The meta-analysis showed high heterogeneity among the studies reviewed (I2 = 94\%; $p=0.00001)$. Out of the seven studies analyzed, six reported a beneficial effect of different strength training methods on anxiety levels [56,61-63]. These six studies showed a large ES in anxiety levels: ES $=-6.93$ through the K10 after concurrent training [61]; ES $=-2.06$ through the PMSIS on both the group that received strength training on the vibration platform and the group that performed conventional strength training [62]; ES $=-1.04$ through the CMAS for the group undergoing concurrent training [56]; and ES = 1.15 and $\mathrm{ES}=1.06$ through the STAI for trait and state, respectively, in a group that carried out concurrent training [63]. However, the research of Costigan et al. [61] presented a higher ES (-6.93) than the rest. On the other hand, one of these seven studies showed no effect after strength and concurrent training on anxiety levels measured by the CMAS (ES = 1.45) [63].

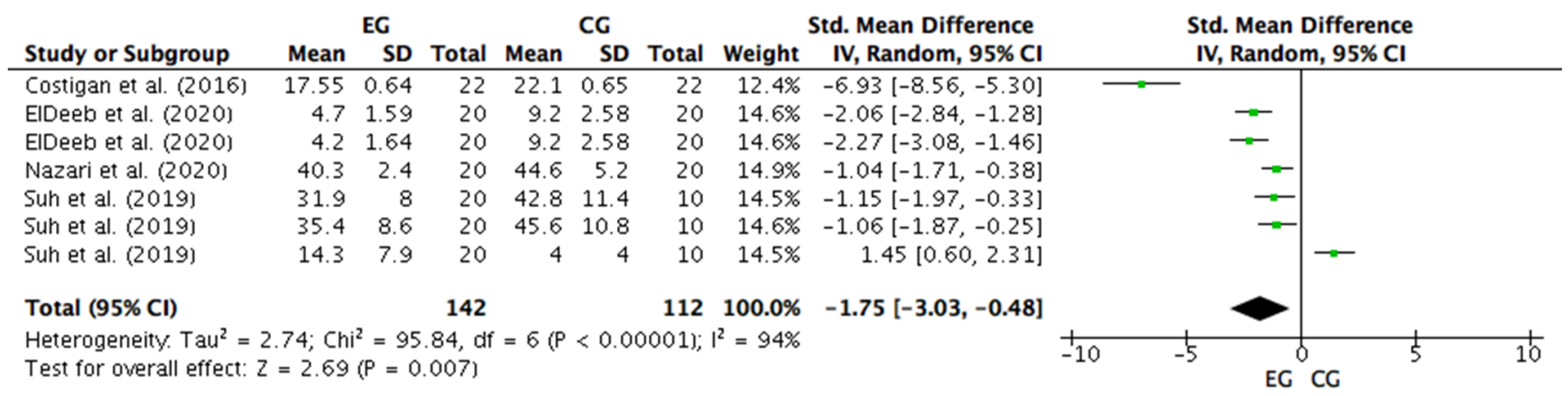

Figure 5. Forest plot comparing the effects of training with different modes of strength intervention on anxiety levels. EG: experimental group; CG: control group; SD: standard deviations.

\subsubsection{Effects of Training with Different Modes of Strength Intervention on Depression Levels}

Six studies were considered for this analysis [57,58,60-63]. However, ElDeeb et al. [62] included two different pieces of training for strength intervention, one on a vibrating platform and another conventional strength training in the research design. Thus, for the meta-analysis, ElDeeb et al.'s [62] study was considered as two independent training protocols. Goldfield et al. [58] used two different pieces of training for strength intervention, one conventional strength training, and another concurrent training that combined aerobic and strength exercises. Thus, the study by Goldfield et al. [58] was also considered as two independent training protocols. On the other hand, Suh et al. [63] included two depression questionnaires in the research with different results. Thus, Suh et al.'s [63] study was considered as two independent designs for the meta-analysis. Therefore, nine studies were considered in the meta-analysis that calculated the effects of training with different modes of strength intervention on depression levels. Figure 6 shows that training with different modes of strength intervention have a large and significant effect on the anxiety level (SMD $=-1.61 ; \mathrm{CI}=95 \%$ : $-2.54,-0.67 ; p=0.0007)$. The meta-analysis showed high heterogeneity among the studies reviewed (I2 $=95 \% ; p=0.00001)$. Of the nine studies analyzed, eight of them reported a beneficial effect of training with different modes of strength intervention on depression levels [57,58,60-63]. Of these eight studies, five showed a large ES in the levels of depression. They measured ES = -6.93 through K10 [61]; ES = -2.15 and ES = -2.51 through the PMSIS in a group that received strength training on a vibrating platform, 
and the group that performed conventional strength training [62]; ES $=-2.49$ through the Brunel Mood Scale (BRUMS) for the group undergoing conventional strength training [58]; and ES $=-1.25$ through the BDI [63]. However, research by Costigan et al. [61] presented a higher ES (-6.93) over the rest. On the other hand, one study showed a moderate ES $(-0.55)$ through the Child and Adolescent Depression Inventory (DIKJ) after strength training on the vibration platform [60]. A study had a small ES (-0.25) in depression through the BRUMS for the group undergoing concurrent training [58]. Finally, out of the eight studies that reported beneficial effects on depression levels after strength training and concurrent intervention, only one obtained a trivial ES $(-0.19)$ in depression through the Children's Depression Inventory 2nd Version (CDI-2), following concurrent training [57]. On the other hand, a study that measured depression through the CDI showed no effect after the conventional strength training intervention $(E S=0.62)$ [63].

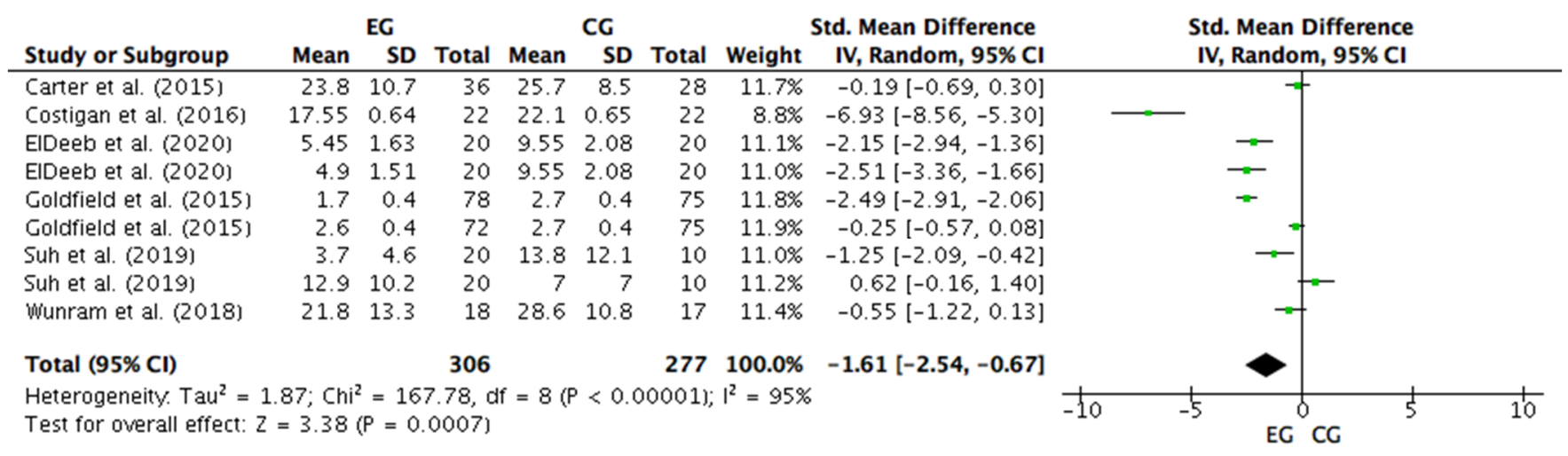

Figure 6. Forest Plot comparing the effects of training with different modes of strength intervention on depression levels. EG: experimental group; CG: control group; SD: standard deviations.

\subsubsection{Effects of Concurrent Training on Depression}

Four studies were considered for this analysis [57,58,61,63]. However, Suh et al. [63] included two depression questionnaires in the research with different results. Thus, Suh et al.'s [63] study was considered as two independent designs for the meta-analysis. Therefore, five studies were considered in the meta-analysis that calculated the effect of concurrent training on depression levels. Figure 7 shows that concurrent training generates a large and significant effect on the anxiety level (SMD $=-1.33 ; \mathrm{CI}=95 \%:-2.55,-0.11$; $p=0.03$ ). The meta-analysis showed high heterogeneity among the studies reviewed (I2 = $95 \% ; p=0.00001$ ). Out of the five studies analyzed, four of them reported a beneficial effect of concurrent training on depression levels $[57,58,61,63]$. Out of these four studies, two of them showed a large ES in levels of depression measured by the K10 (ES = -6.93) [61] and the CDI $(E S=-1.25)$ [63]. However, the study by Costigan et al. [61] presented a higher ES $(-6.93)$ above that of Suh et al. [63]. A study also showed a small ES $(-0.25)$ through the BRUMS [58]. Finally, out of the four studies that reported beneficial effects on depression levels after the concurrent training intervention, only one obtained a trivial ES $(-0.19)$ in depression through the CDI, following concurrent training [57]. On the other hand, a study that measured depression through the CDI showed no effect after the concurrent training intervention $(\mathrm{ES}=0.62)[63]$. 


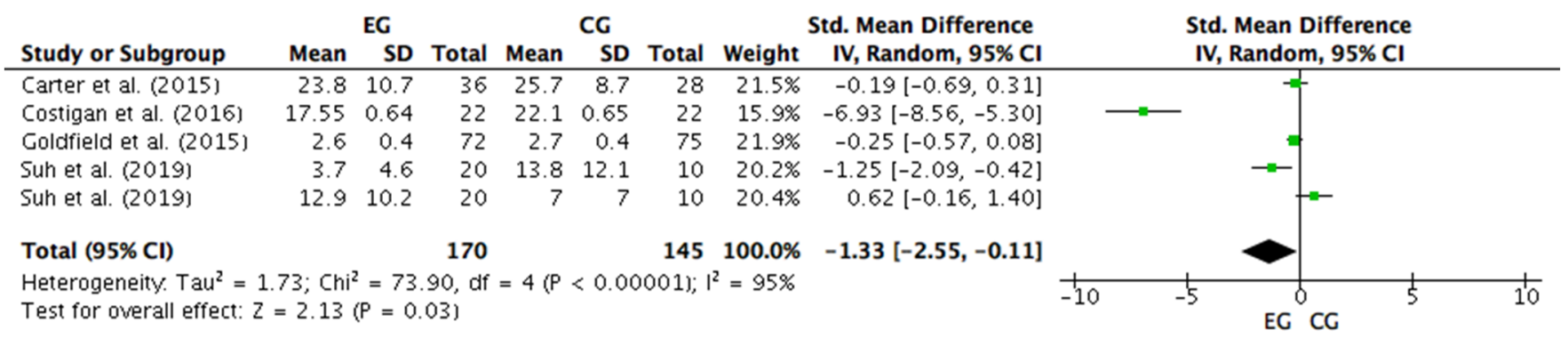

Figure 7. Forest plot comparing the effects of concurrent training on depression levels. EG: experimental group; CG: control group; SD: standard deviations.

\subsubsection{Effects of Conventional and Vibration Platform Strength Training on Depression}

Three studies were considered for this analysis [58,60,62]. However, ElDeeb et al. [62] included two different pieces of training for strength intervention, one conventional and another on a vibrating platform. Therefore, for the meta-analysis, ElDeeb et al.'s [62] study was considered as two independent training protocols. Therefore, four studies were considered in the meta-analysis that calculated the effect of strength training on depression levels. Figure 8 shows that strength training generates a large and significant effect on the level of depression (SMD $=-1.92 ; \mathrm{CI}=95 \%:-2.86,-0.98 ; p=0.0001)$. The meta-analysis showed high heterogeneity among the studies reviewed (I2 $=88 \%$; $p=$ 0.0001). The four studies analyzed declared a beneficial effect of strength training on depression levels $[58,60,62]$. Out of these four studies, three showed a large ES in the levels of depression. The ES was measured through the PMSIS in both the group that received vibration platform strength training $(E S=-2.15)$ and the group that performed conventional strength training ( $E S=-2.51)$ [62], and through the BRUMS in the group that underwent conventional strength training $(E S=-2.49)$ [58]. A study also showed moderate ES through the DIKJ after strength training on the vibration platform $(\mathrm{ES}=$ $-0.55)[60]$.

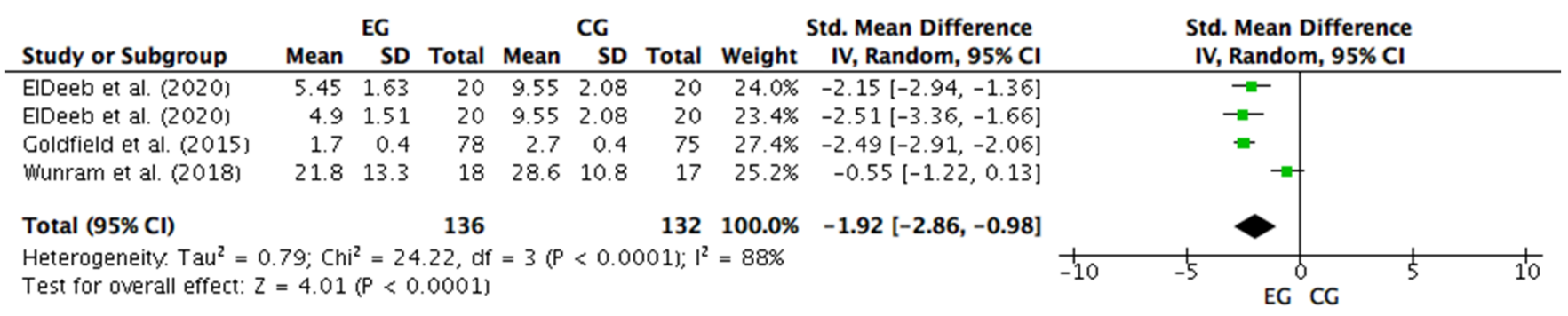

Figure 8. Forest plot comparing the effects of conventional and vibration platform strength training on depression levels. EG: experimental group; CG: control group; SD: standard deviations.

\section{Discussion}

Regarding the studies included in the systematic review and meta-analysis, the results showed that concurrent training [56-58,61,63], conventional strength training [58,59,62], vibration platform strength training $[60,62]$, and strength training through Crossfit ${ }^{\mathrm{TM}}$ Teens [64] had been used to control or decrease the levels of anxiety and depression. Thus, it was possible to demonstrate that physical exercise, through strength training independent of its modality, produces decreases in the levels of anxiety $(E S=-1.75)$ and depression (ES $=-1.61$ ) in 448 adolescent subjects (142 and 306, respectively). Other meta-analyses indicated a small to moderate effect for anxiety [24] and depression [66]. These studies in the adult population determined the effects of strength training on anxiety and depression $[24,66]$. However they included only randomized controlled studies and excluded those studies that combined strength training with another modality, such as 
concurrent training and vibration platform strength training $[24,66]$. This differs from our meta-analysis, which showed a large effect after the training with different modes of strength intervention on anxiety and depression levels in the adolescent population. These differences may be a product of the level of neuroplasticity that exists in adolescents over adults [67], which would allow further modeling of brain development [22] and therefore provide more encouraging benefits for adolescent mental health [67].

\subsection{Physical Performance and Psychosocial Disorders of Anxiety, Stress, and Depression}

At the end of this systematic review, the only physical performance effects reported and associated with strength training were maximum strength and maximum oxygen consumption. However, only three studies evaluated these variables $[59,60,63]$, and only two of these studies showed an increase in physical performance for the groups undergoing strength training [59,63]. In this sense, Gordon et al. [59] intervened in a group with AT and another with ST, showing a decrease in depression variables in both groups. However, the same authors showed an increase $(p=0.05)$ in push-up for the ST group as opposed to the AT group $(p>0.05)$. Likewise, there is evidence that physical exercise through strength training produces different physiological adaptations, such as increased muscle mass, muscle strength, and muscle power [32,33]. These three concepts together are strongly associated with muscle quality [36], which refers to the ability of skeletal muscles to perform several functions effectively, including force production, contraction and relaxation, metabolism, substrate turnover and storage, heat generation, myokine production, and electrical conduction [36]. In this context, the literature has described that low muscle strength levels may reflect weak muscle quality [35], while high muscle quality can help prevent chronic disease [37]. It has also been associated that adolescents who present some chronic diseases have a higher level of anxiety and depressive symptoms [68]. Thus, a possible association between muscle strength and quality with psychosocial disorders could be increased hippocampus and some markers' activation. However, this has not been established; so far, it would only be speculation.

\subsection{Effects of Different Methods of Strength Training Associated with Psychosocial Disorders of Anxiety, Stress, and Depression}

Specifically, strength training through a concurrent method has been the most used to mitigate or decrease anxiety and depression in adolescents $[56-58,61,63]$. In this sense, Wegner et al. [15] showed that the meta-analyses that have studied the effect of physical exercise on depression are mainly studies involving aerobic exercise and not strength training. In this sense, the evidence indicates that aerobic exercise is a favorable alternative for reducing anxiety and depression in children and adolescents [15]. However, the ES $(>0.8)$ obtained in the present meta-analysis suggests that strength training, regardless of its modality, is a good alternative for controlling psychosocial disorders in adolescents [54]. This meta-analysis has shown that both strength training-conventional and through a concurrent-methods present a large ES in the levels of depression. When performing a subdivision of the training methods and determining their effects on depression, concurrent training evidence of an ES $=1.33$ besides a strength training evidence of an ES = 1.92 may indicate more significant depression benefits through conventional strength training over concurrent training. The causes may be the possible physiological interferences that aerobic training would cause on the hypertrophy and muscular strength induced by strength training [69]. Scientific evidence shows that high levels of muscle hypertrophy and strength are stimulated by anabolic hormones such as growth hormone (GH) [70,71] and possibly by insulin-like growth factor-1 (IGF-1) [72]. In this context, it has been described that GH and IGF-1 would have a fundamental role in the growth and maintenance of the central nervous system and the peripheral nervous system [73]. However, other studies [74-76] have shown that high values of IGF-1 are associated with higher levels of depression. Likewise, a recent meta-analysis showed that higher levels of IGF-1 are found in aerobic exercise over strength training [77]. This background may partly explain why there are more significant benefits for depression 
through conventional strength training than through concurrent and aerobic training. However, this history should be taken with caution because the role of IGF-1 is not conclusive for the treatment and diagnosis of depression $[75,78]$. On the other hand, due to the low amount of scientific information, we could not compare the effect of concurrent training and strength training on anxiety levels because there were more studies with concurrent training $[56,61,63]$ over strength training [62].

\subsection{Strength Training and Brain Development Associated with Psychosocial Disorders of Anxiety, Stress, and Depression}

Simultaneously, the meta-analysis showed that strength training, regardless of its modality, presents no evidence of stress levels in adolescents [56-64]. In this sense, Nazari et al. [56] evaluated cortisol levels as a sign of stress [79]; however, in our meta-analysis, it has not been possible to establish this association as cortisol would not be a reliable measure in adolescents [67]. In connection with this, Wu et al. [67] concluded that perceived stress through questionnaires is a more sensitive indicator than cortisol measurement for reflecting emotional states and diagnosing stress levels in adolescents, mainly due to neuroplasticity developmental factors present in adolescents' brains [22,67]. Stress has also been associated with symptoms of anxiety and depression [80]. On the other hand, depression has been associated with stress and reduced hippocampus [81]. In this sense, some studies have found an association between a lower hippocampus volume with more significant depressive symptoms $[19,21]$. Moreover, the hippocampus volume is related to the severity of depressive symptoms and the duration of the illness [82]. Additionally, the literature has described that sedentary behavior may have the potential to negatively influence the brain structure of overweight or obese children [83]. In contrast, physical exercise may have important implications for brain development [16] and, therefore, in psychosocial disorders [23]. Thus, in a study by Feter et al. [84], brain adaptations were evidenced by the increase of the hippocampus volume due to physical exercise. Moreover, there are indications that strength training can generate positive responses in the volume of the hippocampus and an increase in the concentration of IGF-1, which could play an essential role in the creation and protection of neurons $[85,86]$, thus favoring a possible control of psychosocial disorders [23]. However, recently Troyan and Levada [76] showed that patients diagnosed with depressive disorders had higher levels of IGF-1, but lower levels of brain-derived neurotrophic factor (BDNF). Similarly, research conducted on subjects who had died by suicide showed a decrease in BDNF mRNA expression compared to control subjects [87]. At the same time, there is evidence to suggest that antidepressant medications, exercise, and strength training can increase BDNF [88-91], and therefore, the volume of the hippocampus [92] associated with a decrease in psychosocial disorders $[19,21]$. However, studies on the effects of BDNF and other mediators on brain plasticity [93], protection of the hippocampus, and plausible neurobiological adaptations to strength training are lacking $[24,84]$, as well as the role that IGF-1 would have on psychosocial parameters $[74-76,85,86]$ since IGF-1 remains ambiguous for the treatment and diagnosis of depression [75,78] over other markers [94]. Unfortunately, it has not been possible for the meta-analysis to prove these associations between brain and strength training reliably. Despite this, we believe and support the recent research by Gorham et al. [23], who explained that a reduction in psychosocial disorders associated with sports participation may be related to a neural mechanism, because physical exercise would cause an increase in the volume of the hippocampus. However, like these authors [23], we believe that more research is needed to understand the causal relationships between these variables. 


\section{Conclusions}

There are indications that different modes of strength intervention are a suitable methodology for controlling anxiety and depression levels in adolescents. Specifically, our meta-analysis indicates that conventional strength training has better benefits than other modes of strength intervention. However, this field has not been investigated in-depth, thus further experimental studies focusing on strength training to control or mitigate anxiety, stress, and depression levels in the adolescent population are needed. This will allow new public policies and programs to assess, control, and mitigate psychosocial disorders through training that features different modes of strength intervention.

Author Contributions: Conceptualization, G.B.-F. and Á.H.O.; methodology, G.B.-F. and Á.H.O.; formal analysis, G.B.-F., Á.H.O. and L.C.-R.; writing — original draft preparation G.B.-F. and Á.H.O.; writing-review and editing, G.B.-F., Á.H.O. and L.C.-R.; visualization, G.B.-F., Á.H.O. and L.C.-R.; supervision, G.B.-F., Á.H.O. and L.C.-R. All authors have read and agreed to the published version of the manuscript.

Funding: This research received no external funding.

Institutional Review Board Statement: Not applicable.

Informed Consent Statement: Not applicable.

Data Availability Statement: Not applicable.

Acknowledgments: This paper will be part of Guillermo Barahona-Fuentes Doctoral Thesis performed in the Biomedicine Doctorate Program of the University of Granada, Spain.

Conflicts of Interest: The authors declare no conflict of interest.

\section{References}

1. Crempien, C.; De La Parra, G.; Grez, M.; Valdés, C.; López, M.J.; Krause, M. Características sociodemográficas y clínicas de pacientes diagnosticados con depresión en Centros Comunitarios de Salud Mental (COSAM) de Santiago, Chile. Rev. Chil. Neuro-Psiquiatr. 2017, 55, 26-35. [CrossRef]

2. Spielberger, C.D. State-Trait Anxiety Inventory: Bibliography; Consulting Psychologists Press: Santa Clara, CA, USA, 1989.

3. Kent, M. Diccionario Oxford de Medicina y Ciencias del Deporte, 2nd ed.; Editorial Paidotribo: Barcelona, Spain, 2003.

4. Assoc, A.P. Diagnostic and Statistical Manual of Mental Disorders, 5th ed.; American Psychiatric Association: Washington, DC, USA, 2013; Volume 21.

5. Othman, N.; Ahmad, F.; El Morr, C.; Ritvo, P. Perceived impact of contextual determinants on depression, anxiety and stress: A survey with university students. Int. J. Ment. Health Syst. 2019, 13, 1-9. [CrossRef]

6. Barahona-Fuentes, G.D.; Lagos, R.S.; Ojeda, Á.C.H. The influence of self-talk on levels of stress and anxiety in tennis players: A systematic review. Rev. Bras. Cienc. Esporte 2019, 41, 135-141. [CrossRef]

7. Huerta, Á.; Barahona-Fuentes, G.; Galdames, S.; Cáceres, P.; Ortiz, P. Efectos de un programa de Zumba ${ }^{\circledR}$ sobre niveles de ansiedad-rasgo, ansiedad-estado y condición física en estudiantes universitarias chilenas. Cuad. Psicol. Deport. 2020, 20, 1-14. [CrossRef]

8. Nguyen, D.T.; Dedding, C.; Pham, T.T.; Wright, P.; Bunders, J. Depression, anxiety, and suicidal ideation among Vietnamese secondary school students and proposed solutions: A cross-sectional study. BMC Public Health 2013, 13, 195. [CrossRef] [PubMed]

9. Pugh, N.E.; Hadjistavropoulos, H.D. Is anxiety about health associated with desire to exercise, physical activity, and exercise dependence? Personal. Individ. Differ. 2011, 51, 1059-1062. [CrossRef]

10. Gerber, M.; Brand, S.; Elliot, C.; Holsboer-Trachsler, E.; Pühse, U. Aerobic exercise, ball sports, dancing, and weight lifting as moderators of the relationship between stress and depressive symptoms: An exploratory cross-sectional study with Swiss university students. Percept. Mot. Ski. 2014, 119, 679-697. [CrossRef] [PubMed]

11. Ortega, F.B.; Ruiz, J.R.; Castillo, M.J.; Sjöström, M. Physical fitness in childhood and adolescence: A powerful marker of health. Int. J. Obes. 2008, 32, 1-11. [CrossRef]

12. Ensari, I.; Greenlee, T.A.; Motl, R.W.; Petruzzello, S.J. Meta-analysis of acute exercise effects on state anxiety: An update of randomized controlled trials over the past 25 years. Depress. Anxiety 2015, 32, 624-634. [CrossRef]

13. Stonerock, G.L.; Hoffman, B.M.; Smith, P.J.; Blumenthal, J.A. Exercise as Treatment for Anxiety: Systematic Review and Analysis. Ann. Behav. Med. 2015, 49, 542-556. [CrossRef]

14. Stubbs, B.; Vancampfort, D.; Rosenbaum, S.; Firth, J.; Cosco, T.; Veronese, N.; Salum, G.A.; Schuch, F.B. An examination of the anxiolytic effects of exercise for people with anxiety and stress-related disorders: A meta-analysis. Psychiatry Res. 2017, 249, 102-108. [CrossRef] 
15. Wegner, M.; Amatriain-Fernández, S.; Kaulitzky, A.; Murillo-Rodriguez, E.; Machado, S.; Budde, H. Systematic Review of Meta-Analyses: Exercise Effects on Depression in Children and Adolescents. Front. Psychiatry 2020, 11, 1-12. [CrossRef]

16. Wittfeld, K.; Jochem, C.; Dörr, M.; Schminke, U.; Gläser, S.; Bahls, M.; Markus, M.R.P.; Felix, S.B.; Leitzmann, M.F.; Ewert, R.; et al. Cardiorespiratory Fitness and Gray Matter Volume in the Temporal, Frontal, and Cerebellar Regions in the General Population. Mayo Clin. Proc. 2020, 95, 44-56. [CrossRef]

17. Herting, M.M.; Keenan, M.F. Exercise and the developing brain in children and adolescents. In Physical Activity and the Aging Brain; Elsevier: Amsterdam, The Netherlands, 2017; pp. 13-19.

18. Chaddock, L.; Erickson, K.I.; Prakash, R.S.; Kim, J.S.; Voss, M.W.; VanPatter, M.; Pontifex, M.B.; Raine, L.B.; Konkel, A.; Hillman, C.H.; et al. A neuroimaging investigation of the association between aerobic fitness, hippocampal volume, and memory performance in preadolescent children. Brain Res. 2010, 1358, 172-183. [CrossRef]

19. McKinnon, M.C.; Yucel, K.; Nazarov, A.; MacQueen, G.M. A meta-analysis examining clinical predictors of hippocampal volume in patients with major depressive disorder. J. Psychiatry Neurosci. JPN 2009, 34, 41-54.

20. Norbury, R.; Godlewska, B.; Cowen, P.J. When less is more: A functional magnetic resonance imaging study of verbal working memory in remitted depressed patients. Psychol. Med. 2014, 44, 1197-1203. [CrossRef]

21. Rao, U.; Chen, L.-A.; Bidesi, A.S.; Shad, M.U.; Thomas, M.A.; Hammen, C.L. Hippocampal changes associated with early-life adversity and vulnerability to depression. Biol. Psychiatry 2010, 67, 357-364. [CrossRef] [PubMed]

22. Suzuki, H.; Botteron, K.N.; Luby, J.L.; Belden, A.C.; Gaffrey, M.S.; Babb, C.M.; Nishino, T.; Miller, M.I.; Ratnanather, J.T.; Barch, D.M. Structural-functional correlations between hippocampal volume and cortico-limbic emotional responses in depressed children. Cogn. Affect. Behav. Neurosci. 2013, 13, 135-151. [CrossRef]

23. Gorham, L.S.; Jernigan, T.; Hudziak, J.; Barch, D.M. Involvement in Sports, Hippocampal Volume, and Depressive Symptoms in Children. Biol. Psychiatry Cogn. Neurosci. Neuroimaging 2019, 4, 484-492. [CrossRef]

24. Gordon, B.R.; McDowell, C.P.; Lyons, M.; Herring, M.P. The Effects of Resistance Exercise Training on Anxiety: A Meta-Analysis and Meta-Regression Analysis of Randomized Controlled Trials. Sports. Med. 2017, 47, 2521-2532. [CrossRef]

25. Winett, R.A.; Carpinelli, R.N. Potential health-related benefits of resistance training. Prev. Med. 2001, 33, 503-513. [CrossRef]

26. Dias, C.P.; Toscan, R.; de Camargo, M.; Pereira, E.P.; Griebler, N.; Baroni, B.M.; Tiggemann, C.L. Effects of eccentric-focused and conventional resistance training on strength and functional capacity of older adults. AGE 2015, 37, 1-8. [CrossRef]

27. Wilson, J.M.; Marin, P.J.; Rhea, M.R.; Wilson, S.M.C.; Loenneke, J.P.; Anderson, J.C. Concurrent training: A meta-analysis examining interference of aerobic and resistance exercises. J. Strength Cond. Res. 2012, 26, 2293-2307. [CrossRef]

28. Nordlund, M.M.; Thorstensson, A. Strength training effects of whole-body vibration? Scand. J. Med. Sci. Sports 2007, 17, 12-17. [CrossRef]

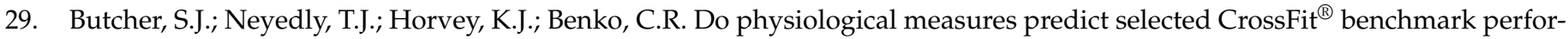
mance? Open Access J. Sports. Med. 2015, 6, 241. [CrossRef]

30. de Hoyo, M.; Gonzalo-Skok, O.; Sañudo, B.; Carrascal, C.; Plaza-Armas, J.R.; Camacho-Candil, F.; Otero-Esquina, C. Comparative effects of in-season full-back squat, resisted sprint training, and plyometric training on explosive performance in U-19 elite soccer players. J. Strength Cond. Res. 2016, 30, 368-377. [CrossRef]

31. Barahona-Fuentes, G.D.; Ojeda, Á.H.; Jerez-Mayorga, D. Effects of different methods of strength training on indicators of muscle fatigue during and after strength training: A systematic review. Mot. Rev. Educ. Física 2020, 26. [CrossRef]

32. Ojeda, Á.H.; Chirosa, L.J.; Barrilao, R.G.; Rios, I.J.C.; Serrano, P.A.C. Efecto de la resistencia variable sobre la potenciación post activación: Una revisión sistemática. Arch. Med. Deporte Rev. Fed. Española Med. Deporte Confed. Iberoam. Med. Deporte 2016, 33, 338-345.

33. Barahona-Fuentes, G.D.F.; Huerta Ojeda, Á.; Galdames Maliqueo, S.A. Influencia de la pliometría basada en un Entrenamiento Intervalado de Alta Intensidad sobre la altura de salto y pico de potencia en futbolistas Sub-17. Educ. Física Y Cienc. 2019, 21, e080. [CrossRef]

34. Sabido, R.; Peñaranda, M.; Hernández-Davó, J.L. Comparison of Acute Responses to Four Different Hypertrophy-Oriented Resistance Training Methodologies. Eur. J. Hum. Mov. 2016, 37, 109-121.

35. Barbat-Artigas, S.; Rolland, Y.; Zamboni, M.; Aubertin-Leheudre, M. How to assess functional status: A new muscle quality index. J. Nutr. Health Aging 2012, 16, 67-77. [CrossRef]

36. Fragala, M.S.; Kenny, A.M.; Kuchel, G.A. Muscle Quality in Aging: A Multi-Dimensional Approach to Muscle Functioning with Applications for Treatment. Sports Med. 2015, 45, 641-658. [CrossRef]

37. Wolfe, R.R. The underappreciated role of muscle in health and disease. Am. J. Clin. Nutr. 2006, 84, 475-482. [CrossRef]

38. Peterson, M.D.; Liu, D.; Gordish-Dressman, H.; Hubal, M.J.; Pistilli, E.; Angelopoulos, T.J.; Clarkson, P.M.; Moyna, N.M.; Pescatello, L.S.; Seip, R.L.; et al. Adiposity attenuates muscle quality and the adaptive response to resistance exercise in non-obese, healthy adults. Int. J. Obes. 2011, 35, 1095-1103. [CrossRef]

39. Fabbri, E.; Chiles Shaffer, N.; Gonzalez-Freire, M.; Shardell, M.D.; Zoli, M.; Studenski, S.A.; Ferrucci, L. Early body composition, but not body mass, is associated with future accelerated decline in muscle quality. J. Cachex Sarcopenia Muscle 2017, 8, 490-499. [CrossRef]

40. Page, M.J.; McKenzie, J.E.; Bossuyt, P.M.; Boutron, I.; Hoffmann, T.C.; Mulrow, C.D.; Shamseer, L.; Tetzlaff, J.M.; Akl, E.A.; Brennan, S.E.; et al. The PRISMA 2020 statement: An updated guideline for reporting systematic reviews. BMJ 2021, 372, n71. [CrossRef] 
41. Waddington, H.; Masset, E.; Jimenez, E. What have we learned after ten years of systematic reviews in international development? J. Dev. Eff. 2018, 10, 1-16. [CrossRef]

42. da Silva, F.C.; Iop, R.d.R.; de Oliveira, L.C.; Boll, A.M.; de Alvarenga, J.G.S.; Gutierres Filho, P.J.B.; de Melo, L.M.A.B.; Xavier, A.J.; da Silva, R. Effects of physical exercise programs on cognitive function in Parkinson's disease patients: A systematic review of randomized controlled trials of the last 10 years. PLoS ONE 2018, 13, e0193113.

43. Beck, A.T.; Ward, C.H.; Mendelson, M.; Mock, J.; Erbaugh, J. An inventory for measuring depression. Arch. Gen. Psychiatry 1961, 4, 561-571. [CrossRef] [PubMed]

44. Kovacs, M. Children's Depression Inventory: Manual; Multi-Health Systems: North Tonawanda, NY, USA, 1992.

45. Terry, P.C.; Lane, A.M.; Fogarty, G.J. Construct validity of the Profile of Mood States-Adolescents for use with adults. Psychol. Sport Exerc. 2003, 4, 125-139. [CrossRef]

46. Wallenstein, G.V.; Blaisdell-Gross, B.; Gajria, K.; Guo, A.; Hagan, M.; Kornstein, S.G.; Yonkers, K.A. Development and validation of the Premenstrual Symptoms Impact Survey (PMSIS): A disease-specific quality of life assessment tool. J. Women's Health 2008, 17, 439-450. [CrossRef]

47. Speilberger, C.D.; Vagg, P.R. Psychometric properties of the STAI: A reply to Ramanaiah, Franzen, and Schill. J. Personal. Assess. 1984, 48, 95-97. [CrossRef] [PubMed]

48. Reynolds, C.R.; Richmond, B.O. What I think and feel: A revised measure of children's manifest anxiety. J. Abnorm. Child Psychol. 1978, 6, 271-280. [CrossRef] [PubMed]

49. Andrews, G.; Slade, T. Interpreting scores on the Kessler psychological distress scale (K10). Aust. N. Z. J. Public Health 2001, 25, 494-497. [CrossRef] [PubMed]

50. Muris, P.; Meesters, C.; Fijen, P. The self-perception profile for children: Further evidence for its factor structure, reliability, and validity. Personal. Individ. Differ. 2003, 35, 1791-1802. [CrossRef]

51. Egger, M.; Smith, G.D.; Schneider, M.; Minder, C. Bias in meta-analysis detected by a simple, graphical test. Br. Med. J. 1997, 315, 629. [CrossRef]

52. Higgins, J.P.T.; Thomas, J.; Chandler, J.; Cumpston, M.; Li, T.; Page, M.J.; Welch, V.A. Cochrane Handbook for Systematic Reviews of Interventions; John Wiley \& Sons: Hoboken, NJ, USA, 2019.

53. Hedges, L.V. Distribution theory for Glass's estimator of effect size and related estimators. J. Educ. Stat. 1981, 6, 107-128. [CrossRef]

54. Cohen, J. Statistical Power Analysis for the Behavioral Sciences; Academic Press: Cambridge, MA, USA, 2013 ; ISBN 1483276481.

55. Higgins, J.; Thompson, S.; Deeks, J.; Altman, D. Measuring inconsistency in meta-analyses. BMJ 2003, 327, 557-560. [CrossRef]

56. Nazari, M.; Shabani, R.; Dalili, S. The effect of concurrent resistance-aerobic training on serum cortisol level, anxiety, and quality of life in pediatric type 1 diabetes. J. Pediatr. Endocrinol. Metab. 2020, 33, 599-604. [CrossRef]

57. Carter, T.; Guo, B.; Turner, D.; Morres, I.; Khalil, E.; Brighton, E.; Armstrong, M.; Callaghan, P. Preferred intensity exercise for adolescents receiving treatment for depression: A pragmatic randomised controlled trial. BMC Psychiatry 2015, 15, 1-12. [CrossRef]

58. Goldfield, G.S.; Alberga, A.S.; Hadjiyannakis, S.; Phillips, P.; Malcolm, J.; Wells, G.A.; Kenny, G.P.; Prud'homme, D.; Gougeon, R.; Tulloch, H.; et al. Effects of Aerobic Training, Resistance Training, or Both on Psychological Health in Adolescents with Obesity: The HEARTY Randomized Controlled Trial. J. Consult. Clin. Psychol. 2015, 83, 1123-1135. [CrossRef]

59. Gordon, B.A.; Knapman, L.M.; Lubitz, L. Graduated exercise training and progressive resistance training in adolescents with chronic fatigue syndrome: A randomized controlled pilot study. Clin. Rehabil. 2010, 24, 1072-1079. [CrossRef]

60. Wunram, H.L.; Hamacher, S.; Hellmich, M.; Volk, M.; Jänicke, F.; Reinhard, F.; Bloch, W.; Zimmer, P.; Graf, C.; Schönau, E.; et al. Whole body vibration added to treatment as usual is effective in adolescents with depression: A partly randomized, three-armed clinical trial in inpatients. Eur. Child Adolesc. Psychiatry 2018, 27, 645-662. [CrossRef] [PubMed]

61. Costigan, S.A.; Eather, N.; Plotnikoff, R.C.; Hillman, C.H.; Lubans, D.R. High-Intensity Interval Training for Cognitive and Mental Health in Adolescents. Med. Sci. Sports Exerc. 2016, 48, 1985-1993. [CrossRef]

62. ElDeeb, A.; Atta, H.; Osman, D. Effect of whole body vibration versus resistive exercise on premenstrual symptoms in adolescents with premenstrual syndrome. Bull. Fac. Phys. Ther. 2020, 25, 1-6. [CrossRef]

63. Suh, J.; Choi, H.S.; Kwon, A.; Chae, H.W.; Eom, S.; Kim, H.S. Once-weekly supervised combined training improves neurocognitive and psychobehavioral outcomes in young patients with type 1 diabetes mellitus. J. Pediatr. Endocrinol. Metab. 2019, 32, 1341-1350. [CrossRef] [PubMed]

64. Eather, N.; Morgan, P.J.; Lubans, D.R. Effects of exercise on mental health outcomes in adolescents: Findings from the CrossFit ${ }^{\mathrm{TM}}$ teens randomized controlled trial. Psychol. Sport Exerc. 2016, 26, 14-23. [CrossRef]

65. Goodman, R.; Meltzer, H.; Bailey, V. The Strengths and Difficulties Questionnaire: A pilot study on the validity of the self-report version. Eur. Child Adolesc. Psychiatry 1998, 7, 125-130. [CrossRef] [PubMed]

66. Carneiro, L.; Afonso, J.; Ramirez-Campillo, R.; Murawska-Ciałowciz, E.; Marques, A.; Clemente, F.M. The effects of exclusively resistance training-based supervised programs in people with depression: A systematic review and meta-analysis of randomized controlled trials. Int. J. Environ. Res. Public Health 2020, 17, 6715. [CrossRef]

67. Wu, J.; Tong, H.; Liu, Z.; Tao, J.; Chen, L.; Chan, C.C.H.; Lee, T.M.C. Neurobiological effects of perceived stress are different between adolescents and middle-aged adults. Brain Imaging Behav. 2021, 15, 846-854. [CrossRef] 
68. Lacomba-Trejo, L.; Valero-Moreno, S.; Montoya-Castilla, I.; Pérez-Marín, M. Psychosocial Factors and Chronic Illness as Predictors for Anxiety and Depression in Adolescence. Front. Psychol. 2020, 11, 2529. [CrossRef] [PubMed]

69. Coffey, V.G.; Hawley, J.A. Concurrent exercise training: Do opposites distract? J. Physiol. 2017, 595, 2883-2896. [CrossRef]

70. Kraemer, W.J.; Ratamess, N.A.; Nindl, B.C. Recovery responses of testosterone, growth hormone, and IGF-1 after resistance exercise. J. Appl. Physiol. 2017, 122, 549-558. [CrossRef]

71. Schoenfeld, B.J. The mechanisms of muscle hypertrophy and their application to resistance training. J. Strength Cond. Res. 2010, 24, 2857-2872. [CrossRef]

72. Wackerhage, H.; Schoenfeld, B.J.; Hamilton, D.L.; Lehti, M.; Hulmi, J.J. Stimuli and sensors that initiate skeletal muscle hypertrophy following resistance exercise. J. Appl. Physiol. 2019, 126, 30-43. [CrossRef]

73. Bianchi, V.E.; Locatelli, V.; Rizzi, L. Neurotrophic and neuroregenerative effects of GH/IGF1. Int. J. Mol. Sci. 2017, 18, 2441. [CrossRef]

74. Levada, O.A.; Troyan, A.S.; Pinchuk, I.Y. Serum insulin-like growth factor-1 as a potential marker for MDD diagnosis, its clinical characteristics, and treatment efficacy validation: Data from an open-label vortioxetine study. BMC Psychiatry 2020, 20, 1-10. [CrossRef]

75. Sharma, A.N.; Soares, J.C.; Carvalho, A.F.; Quevedo, J. Role of trophic factors GDNF, IGF-1 and VEGF in major depressive disorder: A comprehensive review of human studies. J. Affect. Disord. 2016, 197, 9-20. [CrossRef]

76. Troyan, A.S.; Levada, O.A. The Diagnostic Value of the Combination of Serum Brain-Derived Neurotrophic Factor and Insulin-Like Growth Factor-1 for Major Depressive Disorder Diagnosis and Treatment Efficacy. Front. Psychiatry 2020, 11, 800. [CrossRef]

77. de Alcantara Borba, D.; da Silva Alves, E.; Rosa, J.P.P.; Facundo, L.A.; Costa, C.M.A.; Silva, A.C.; Narciso, F.V.; Silva, A.; de Mello, M.T. Can IGF-1 Serum Levels Really be Changed by Acute Physical Exercise? A Systematic Review and Meta-Analysis. J. Phys. Act. Health 2020, 17, 575-584. [CrossRef] [PubMed]

78. Carvalho, A.F.; Köhler, C.A.; McIntyre, R.S.; Knöchel, C.; Brunoni, A.R.; Thase, M.E.; Quevedo, J.; Fernandes, B.S.; Berk, M. Peripheral vascular endothelial growth factor as a novel depression biomarker: A meta-analysis. Psychoneuroendocrinology 2015, 62, 18-26. [CrossRef]

79. Smyth, J.; Ockenfels, M.C.; Porter, L.; Kirschbaum, C.; Hellhammer, D.H.; Stone, A.A. Stressors and mood measured on a momentary basis are associated with salivary cortisol secretion. Psychoneuroendocrinology 1998, 23, 353-370. [CrossRef]

80. Fiksdal, A.; Hanlin, L.; Kuras, Y.; Gianferante, D.; Chen, X.; Thoma, M.V.; Rohleder, N. Associations between symptoms of depression and anxiety and cortisol responses to and recovery from acute stress. Psychoneuroendocrinology 2019, 102, 44-52. [CrossRef]

81. Burke, H.M.; Davis, M.C.; Otte, C.; Mohr, D.C. Depression and cortisol responses to psychological stress: A meta-analysis. Psychoneuroendocrinology 2005, 30, 846-856. [CrossRef]

82. Cheng, Y.; Xu, J.; Chai, P.; Li, H.; Luo, C.; Yang, T.; Li, L.; Shan, B.; Xu, X.; Xu, L. Brain volume alteration and the correlations with the clinical characteristics in drug-naive first-episode MDD patients: A voxel-based morphometry study. Neurosci. Lett. 2010, 480, 30-34. [CrossRef] [PubMed]

83. Zavala-Crichton, J.P.; Esteban-Cornejo, I.; Solis-Urra, P.; Mora-Gonzalez, J.; Cadenas-Sanchez, C.; Rodriguez-Ayllon, M.; Migueles, J.H.; Molina-Garcia, P.; Verdejo-Roman, J.; Kramer, A.F.; et al. Association of Sedentary Behavior with Brain Structure and Intelligence in Children with Overweight or Obesity: The ActiveBrains Project. J. Clin. Med. 2020, 9, 1101. [CrossRef] [PubMed]

84. Feter, N.; Penny, J.C.; Freitas, M.P.; Rombaldi, A.J. Effect of physical exercise on hippocampal volume in adults: Systematic review and meta-analysis. Sci. Sports 2018, 33, 327-338. [CrossRef]

85. Morel, G.R.; León, M.L.; Uriarte, M.; Reggiani, P.C.; Goya, R.G. Therapeutic potential of IGF-I on hippocampal neurogenesis and function during aging. Neurogenesis 2017, 4, e1259709. [CrossRef]

86. Nieto-Estévez, V.; Defterali, Ç.; Vicario-Abejón, C. IGF-I: A key growth factor that regulates neurogenesis and synaptogenesis from embryonic to adult stages of the brain. Front. Neurosci. 2016, 10, 52. [CrossRef]

87. Dwivedi, Y.; Rizavi, H.S.; Conley, R.R.; Roberts, R.C.; Tamminga, C.A.; Pandey, G.N. Altered gene expression of brain-derived neurotrophic factor and receptor tyrosine kinase B in postmortem brain of suicide subjects. Arch. Gen. Psychiatry 2003, 60, 804-815. [CrossRef]

88. Azevedo, K.P.M.; de Oliveira, V.H.; Medeiros, G.C.B.S.; Mata, Á.N.d.S.; García, D.Á.; Martínez, D.G.; Leitão, J.C.; Knackfuss, M.I.; Piuvezam, G. The Effects of Exercise on BDNF Levels in Adolescents: A Systematic Review with Meta-Analysis. Int. J. Environ. Res. Public Health 2020, 17, 6056. [CrossRef]

89. Hung, C.-L.; Tseng, J.-W.; Chao, H.-H.; Hung, T.-M.; Wang, H.-S. Effect of acute exercise mode on serum brain-derived neurotrophic factor (BDNF) and task switching performance. J. Clin. Med. 2018, 7, 301. [CrossRef] [PubMed]

90. Marinus, N.; Hansen, D.; Feys, P.; Meesen, R.; Timmermans, A.; Spildooren, J. The Impact of Different Types of Exercise Training on Peripheral Blood Brain-Derived Neurotrophic Factor Concentrations in Older Adults: A Meta-Analysis. Sports Med. 2019, 49, 1529-1546. [CrossRef]

91. Polyakova, M.; Stuke, K.; Schuemberg, K.; Mueller, K.; Schoenknecht, P.; Schroeter, M.L. BDNF as a biomarker for successful treatment of mood disorders: A systematic \& quantitative meta-analysis. J. Affect. Disord. 2015, 174, 432-440. [PubMed]

92. Erickson, K.I.; Miller, D.L.; Roecklein, K.A. The aging hippocampus: Interactions between exercise, depression, and BDNF. Neuroscience 2012, 18, 82-97. [CrossRef] 
93. Müller, P.; Duderstadt, Y.; Lessmann, V.; Müller, N.G. Lactate and BDNF: Key Mediators of Exercise Induced Neuroplasticity? J. Clin. Med. 2020, 9, 1136. [CrossRef]

94. Scarr, E.; Millan, M.J.; Bahn, S.; Bertolino, A.; Turck, C.W.; Kapur, S.; Möller, H.-J.; Dean, B. Biomarkers for psychiatry: The journey from fantasy to fact, a report of the 2013 CINP think tank. Int. J. Neuropsychopharmacol. 2015, 18, pyv042. [CrossRef] [PubMed] 